\title{
Diversity and spatial distribution of black flies (Diptera: Simuliidae) in the Ijuí river drainage basin, Rio Grande do Sul, Brazil
}

\author{
Tieli Cláudia Menzel ${ }^{\bowtie}$, Sirlei Maria Hentges, David Augusto Reynalte Tataje \& Milton Norberto Strieder
}

Universidade Federal da Fronteira Sul - UFFS - Programa de Pós-Graduação em Ambiente e Tecnologias Sustentáveis - PPGATS.

\section{EntomoBrasilis 12 (2): 47-56 (2019)}

\begin{abstract}
In southern Brazil there are several problems regarding the hematophageal activity of black flies, and the information on the distribution of species are still insufficient. In this study, our main goals were to recognize Simuliidae species and to analyze abiotic factors regarding the distribution of immature stages (larva and pupa) in streams from the Ijuí River basin, Northwest of Rio Grande do Sul, Brazil. We sampled simulids specimens in 27 study sites, covering three regions (high, intermediate and low altitude). Concomitantly, we recorded abiotic factors in the studied sites, such as: temperature, electrical conductivity, dissolved oxygen, atmospheric pressure, $\mathrm{pH}$, altitude and stream width. For data analysis, we performed Kruskal-Wallis, ANOVA, Principal Component Analysis (PCA), Analysis of Indicator Species and Canonical Correspondence (CCA). A total of 10 species of black Flies was recorded. Simulium pertinax Kollar, Simulium incrustatum Lutz and Simulium orbitale Lutz were the most frequent. There was no significant difference in richness and density of the species between the different regions studied, except for Simulium jujuyense Paterson \& Shannon. The sampled environments were segregated according to the location within the basin, and only $S$. jujuyense was considered an indicator species of the upper region. These results can be explained by the homogeneous conditions of the Ijuí River basin, which have suffered anthropogenic pressure mainly due to agricultural activities, resulting in losses in local aquatic biodiversity. Also, it may indicate that the control must be conducted considering the basin as a whole, and not only as isolated stretches of the streams.
\end{abstract}

Keywords: Altitudinal gradient; Aquatic insects; Community ecology; Neotropical streams; Simulids.

\section{Diversidade e distribuição espacial de borrachudos (Diptera: Simuliidae) na bacia hidrográfica do rio Ijuí, Rio Grande do Sul, Brasil}

Resumo. No sul do Brasil existem problemas com atividade hematofágica de borrachudos e as informações referentes à distribuição das espécies ainda são insuficientes. O presente estudo visa reconhecer as espécies de Simuliidae e analisar fatores abióticos quanto a distribuição dos estágios imaturos (larva e pupa) em riachos da Bacia do Rio Ijuí, no Noroeste do Rio Grande do Sul, Brasil. Foram coletados simulídeos em 27 pontos de estudo, cobrindo três regiões da bacia (alta, intermediária e baixa altitude). Concomitantemente, foi feito o registro de fatores abióticos nos trechos estudados, tais como: temperatura, condutividade elétrica, oxigênio dissolvido, pressão atmosférica, pH, altitude e largura do riacho. Foram realizadas análises de Kruskal-Wallis ou ANOVA, Análise de Componentes Principais (PCA), Análise de Espécie Indicadora e de Correspondência Canônica (CCA). Foi registrado um total de 10 espécies de Simuliidae. Simulium pertinax Kollar, Simulium incrustatum Lutz e Simulium orbitale Lutz foram as mais frequentes. Não ocorreu diferença na riqueza e na densidade das espécies entre as diferentes regiões estudadas, exceto para Simulium jujuyense Paterson \& Shannon. Os ambientes nos pontos de amostragem foram segregados de acordo com a sua localização na bacia, e apenas $S$. jujuyense foi considerada uma espécie indicadora da região alta. Tais resultados podem ser explicados pelas condições homogêneas da Bacia do Rio Ijuí, que vêm sofrendo pressão antropogênica principalmente devido às atividades agrícolas, resultando em perdas na biodiversidade aquática local. Também, indicam que o controle deve ser realizado considerando a bacia como um todo e não apenas em trechos isolados dos riachos.

Palavras-chave: Ecologia de comunidades; Gradiente altitudinal; Insetos aquáticos; Riachos Neotropicais; Simulídeos.

Tु: he family Simuliidae (Diptera: Culicomorpha) is a large and diverse group of aquatic insects, with 2,328 species registered as valid (ADLER 2019). There black fly faunae were recorded in all continents except Antarctica and are more common in streams from tropical and subtropical regions (HAMADA et al. 2002; MCCREADIE et al. 2005). Due to hematophagy in adult stage, such species represent a sanitary issue. When they feed may causes allergic responses in the host and can be vectors of etiological agents such as Onchocerca volvulus Leuckart and Mansonella ozzardi Manson (SHELLEY et al. 2010).

In Brazil, most of the researches regarding black flies were developed in the Amazonian and Atlantic Forest Biomes
Edited by:

Alberto Moreira Silva-Neto

\section{Article History:}

Received: 14.iii.2019

Accepted: 20.v.2019
Corresponding author:

Tieli Cláudia Menzel

乃 tielimenzel@hotmail.com

(D) No ORCID record
Funding agencies:

$\Delta$ Without funding declared 
(FIGUEIRó \& GIL-AZEvEDo 2010). In a work conducted in the Rio Grande do Sul state about hematophagy activities of adult black flies, a greater species diversity and higher population rates were reported between August and December (STRIEDER \& CORSEUIL 1992). Therefore, it is necessary to increase the knowledge regarding local abundance and regional distribution patterns of species, as well as mesohabitats and microhabitats preferences, in order to properly define and apply efficient population and prevention of diseases control methods (STRIEDER 2005; FigueIró et al. 2008; PEPINELLI 2008).

According to BEGON et al. (2006), researches focused on obtaining a better knowledge of species distribution patterns, as well as their abundances, may provide essential information regarding the most important factors influencing a community structure. As a result, such studies may contribute to identify factors that may modify the local biodiversity, thus providing subsidies for the conservation of environments. Information on the spatial distribution of black flies in flowing water, which represents the main areas where lothic conditions are suitable for the development of immature stages (streams, creeks, or rivers), are essential to distinguish distribution patterns that were caused by anthropic influence from those of natural occurrence (STRIEDER et al. 2002; STRIEDER 2005; STRIEDER et al. 2006; Docile et al. 2015; BufFolo et al. 2016).

Different from other groups of aquatic organisms, morphological and cytotaxonomic approaches of black flies are well developed and advanced (ADLER et al. 2004). Consequently, these organisms may serve as models for the study of a lotic community structure and may be good bioindicators of moderately impacted streams (Adler \& McCreadie 1997; MCCreadie \& Adler 1998; Docile et al. 2015). Although ubiquitous, the ecology of these insects remains poorly understood, particularly in the Neotropical Region (HAMAda et al. 2002; CAMPOS-DE-Oliveira et al. 2015).

Many studies have shown that black fly diversity and local distributions may change due to several abiotic factors in lothic environments within watersheds, including altitude (KuvANGKADIlOK et al. 1999; MALMQvist et al. 1999; Feld et al. 2002; ADLER et al. 2004; MCCREADIE et al. 2006; IlLÉSOvÁ et al. 2008; LANDEIRO et al. 2009; RABHA et al. 2013; SRISUKA et al. 2015). CoucEIRo et al. (2014), in a work conducted in the Rio Grande do Sul state, found a stochastic distribution pattern, in other words, the species richness was not correlated with any sampled variable (environmental or spatial), having as justification possible disturbances that tend to homogenize environments, especially agricultural practices. According to these authors, changes in the specific composition of preimaginal stages of this insect group suggest habitat degradation in streams, as it can act as monitors of the superficial water condition.

According to YA'COB et al. (2016), researches conducted in different altitudes aiming the recognition of distribution patterns in watersheds are important to understand local biodiversity and geographic distribution of species. In this sense, we aimed to evaluate factors influencing the species richness and distribution patterns of black flies in streams. The main goal of this study was to recognize the biodiversity, as well as to investigate the spatial distribution of species and the abiotic factors associated to it, along an altitudinal gradient in the Ijuí River Basin, mesoregion of Northwest Rio Grande do Sul state, South Brazil. Furthermore, to verify if there is an indicator species of some region of the basin (high, intermediate, low).

\section{MATERIAL AND METHODS}

Study sites. The Ijuí River Drainage Basin is located in the Mesoregion of Northwest Rio Grande do Sul state, Brazil, between the geographic coordinates $27^{\circ} 45^{\prime} \mathrm{S}$ and $26^{\circ} 15^{\prime} \mathrm{S}$ of latitude e $53^{\circ} 15^{\prime} \mathrm{W}$ and $56^{\circ} 45^{\prime} \mathrm{W}$ of longitude. This basin has extremely importance as a tributary of the left bank of the large
Uruguay River Basin. The Uruguay River Basin is characterized by agricultural land use, mainly after the 1970 s (TUCCI 2003). In the Ijuí River Basin, the main uses are agricultural and urban (TRINDADE et al. 2018), where the human occupation near the boundaries contributed to environmental degradation (Ferreira 2011). According to Melo et al. (2015a), the main crops are soybean, corn and wheat.

According to WOLLMANN \& GALVANI (2012), the climate of this region is Cfa (Köppen's classification), with an average annual temperature between 17 and $20{ }^{\circ} \mathrm{C}$, and an average annual precipitation of 1,700 to $1,800 \mathrm{~mm}$. Moreover, the relief consists mainly of "coxilhas" (far-reaching plains, which do not exceed an altitude of $200 \mathrm{~m}$, interspersed by subtle waves), with declivities between $3 \%$ and 15\%, formed on basaltic rock (LEINZ 1949).

Sampling and species identification. For estimating local species richness and distribution of immature forms of Simuliidae, we sampled 27 sites along the Ijuí River Drainage Basin during the period of August to October of 2015, comprising 13 municipalities in the Northwest region of Rio Grande do Sul, Brazil.

The sampled area covered the three main regions of the basin (high, intermediate, and low altitude), through a stratified sampling method, where eight sites were sampled in the high altitudinal stratum, eight sites in the intermediate altitudinal stratum, and 11 sites were sampled in the low altitudinal stratum of the Ijuí River Basin (Figure 1).

The sampling sites have been determined by the presence of high-flow streams, and each sampling duration was about 30 to 40 min. Streams were sampled from downstream to upstream, in a stretch of approximately $30 \mathrm{~m}$. The study was conducted during Spring, because this is the season of higher Simuliidae species diversity and population rates in South Brazil (STRIEDER \& CORSEUIL 1992).

In each sampling site, larvae and pupae black flies were collected by hand (using a fine forceps) and stored in bottles with 70\% ethanol. The collections were made by two people, one for each substrate sampled: (1) rocks, and (2) vegetation, including branches, leaves, and roots.

A portable multiparameter meter was used to obtain measurements of abiotic factors of the sampled sites, such as temperature $\left({ }^{\circ} \mathrm{C}\right)$, electrical conductivity $(\mu \mathrm{S} / \mathrm{cm})$, oxygen dissolved $(\mathrm{mg} / \mathrm{L})$, atmospheric pressure $(\mathrm{mm} \mathrm{Hg}$ ) and $\mathrm{pH}$. With a measuring tape, according to protocols proposed by MCCREADIE et al. (2006), we estimated the width of the streams. In addition, we obtained geographic coordinates and altitude of each sampling site through the software Google Earth.

The immature stages of black flies (larvae and pupae) were separated and classified according to the morphotype. Only those which were in the final instar of development (i.e., those with fully developed gill histoblasts) were considered for identification. Thus, it was possible to obtain a better accuracy in the identification of species, due to the lack of specific morphological characteristics in the younger forms of larvae (STRIEDER \& Py-DANIEL 1999).

For species identification, we observed external characters of morphology, using stereomicroscope, as well as taxonomic literature, especially CosCARón (1991). After individual counting, all biological material was deposited put in the biologic collection of the Zoology Lab from the Universidade Federal da Fronteira Sul - UFFS, campus Cerro Largo, Rio Grande do Sul, Brazil.

Data analysis. The frequency of occurrence (FO) was calculated from the total individual's number of each species divided by the 


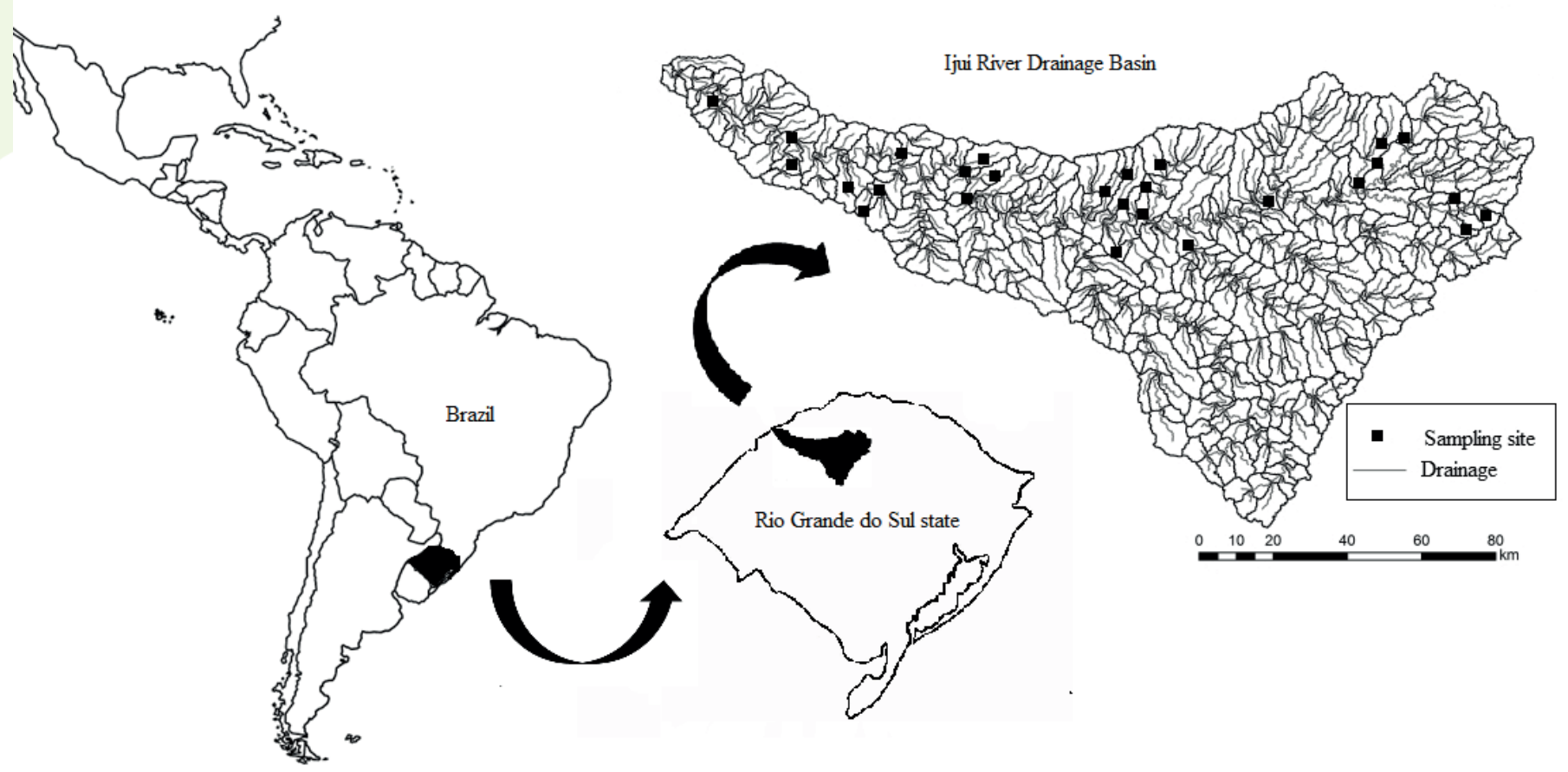

Figure 1. Sampling sites in the Ijuí River Drainage basin, RS, Brazil.

number of all sampled individuals $(\mathrm{n}=9,038)$ and expressed as percentages (HAMADA et al. 2002).

Stream occurrence was determined by the number of sample sites in which a species was found, divided by the total number of sampled sites $(\mathrm{n}=27)$, and expressed as percentages (YA'COB et al. 2016).

The abundance of species per region of the basin was calculated through the total of individuals of a species in a certain region in relation to the total of individuals in all regions. In order to determine the average number of species per water stream, we calculated a simple arithmetic mean and standard deviation between the number of sampled species in all streams.

In order to evaluate if there are differences between the total abundance of species and species richness among three regions of the watershed, we used a non-parametric Kruskal-Wallis test, since all the data did not present the assumptions of the analysis of variances (ANOVA). Furthermore, the same analysis was applied separately for each species found in both regions, followed by the Nemenyi multiple comparison test, when needed. For both species' abundance (total and separately) and richness, the means followed by the standard deviation for each study region were calculated. RStudio software (version 3.4.0) was used.

Individuals' abundances were $\log$ transformed $[\log (x+1)]$ (in which $\mathrm{x}$ represents the organisms' abundance of each species). Normality of data was evaluated through the KolmogorovSmirnov test, and the homogeneity of variances by Levene's test.

The Principal Component Analysis (PCA) was used to evaluate similarities of abiotic factors among sampling sites (LEGENDRE \& LEGENDRE 1998). Since many of the variables are inter-correlated, PCA enables a reduction in independent statistically groups or major components (PCs) (MCCREADIE et al. 1995). A correlation matrix was used to identify highly correlated factors that were removed from the ordering. Because variables were measured at different scales, at first, they were standardized. Axes with eigenvalues greater than 1.0 were accepted for interpretation according to the Kaiser-Guttman criterion, and only variables of loads greater than 0.4 were considered to form the axes (JACKSON 1993), in order to correctly identify explanatory variables of data variability. The Principal Component Analysis (PCA) was performed using the software PC-ORD (version 5.0).

The ANOVA was used to test for significant differences between the different parts of the Ijuí River in relation to the abiotic factors, as well as the Tukey test at $5 \%$ of significance, to identify the respective inequalities. In addition, means and standard deviation of the investigated parameters were calculated. These analyses were performed using RStudio software (version 3.4.0).

In order to evaluate the relationship between abiotic factors and the distribution of black fly species in the studied area, a Canonical Correspondence Analysis (CCA) was performed (ILLÉsová et al. 2010). The technique was used in order to verify the patterns in the abundance of species which are better explained through environmental variables. For testing statistical significance of the species-environment relationship we used a Monte Carlo test with 1000 randomizations. For the CCA analysis, we also used the PC-ORD software (version 5.0).

The indicator species analysis (DUFRENE \& LEGENDRE 1997) combines an abundance of a species with its frequency in the respective sampling site, thereby determining if some species presents specificity for some site. Therefore, we performed this test using the most abundant species of this study, to verify if any of them can be considered an indicator of some of the three regions of the Ijuí River (high, intermediate and low), through the PC-ORD software (version 5.0).

\section{RESULTS}

In total, we collected 47,551 black fly immature individuals (larvae and pupae), obtained in 27 sample sites in the Ijuí River Basin. For analyses, however, we used only 9,038 specimens of those, which was the number equivalent to both final-instar larvae and pupae, and both substrates which were investigated, vegetation and rocks.

Were identified ten species of black flies in the Ijuí River Basin, Rio Grande do Sul, Brazil. The specie Simulium pertinax Kollar was the most abundant, representing $61.35 \%$ of the total sample, followed by Simulium incrustatum Lutz (26.53\%) and Simulium orbitale Lutz (4.81\%). The remaining $7.31 \%$ were represented by the other species (Table 1 ). 
Table 1. Abundance of black flies, Frequency of Occurrence (FO), Stream Occurrence (SO) and Abundance by region for the Ijuí River Basin, August to October 2015.

\begin{tabular}{lccccc}
\hline \multicolumn{1}{c}{ Species } & $\begin{array}{c}\text { Specimens } \\
\left(\mathbf{n}^{\mathbf{0})}\right.\end{array}$ & \% FO & \% SO & \multicolumn{3}{c}{ Abundance by region (\%) } \\
Low
\end{tabular}

The greatest richness found per sampled site was seven species, which was found in five sample sites. The lowest species richness per sampled site was two species, recorded in only one location. The average number of species per stream was $4.96( \pm 1.28)$.

Most black flies were collected in the low region of the Ijuí River, totaling 4,275 specimens (47.30\%), followed by high region (28.21\%) and intermediate region (24.49\%). However, we did not find significant differences between the total abundance of species per studied region (Figure 2). When considering each species separately, only Simulium jujuyense Paterson \& Shannon showed significant differences between the high and intermediate regions (Figure 3). Species richness also did not differ between the three regions (Figure 4).

It was possible to verify a segregation between the different environments, when looking at the two axes which were retained for interpretation, and together accounted for $74.3 \%$ of the total data (Figure 5), as well as a segregation between the different environments. The PCA1 shows a segregation gradient according to the geographic position of each site along the river. The highest points of the basin are located on the right side of the chart, the midpoints in an intermediate position and the lowest points on the left side. These last points (which are those with lower altitude) are characterized by higher temperature, electrical conductivity, and riparian width (Table 2). Details on the main values of variables in the 27 sampling points are presented in Attachment 1, and differences between abiotic factors per region in Attachment 2.

We did not find any relationship between the species and the abiotic factors data sampled in different environments of the Ijuí River Basin ( $p>0.05)$, i.e., the distribution of species in biotopes follows a homogeneous pattern. Furthermore, $S$. jujuyense was the only species pointed as an indicator of the upper region of the drainage basin $(\mathrm{p}<0.05)$, while other species showed no specificity for any specific region, according to the results of the indicator species analysis.

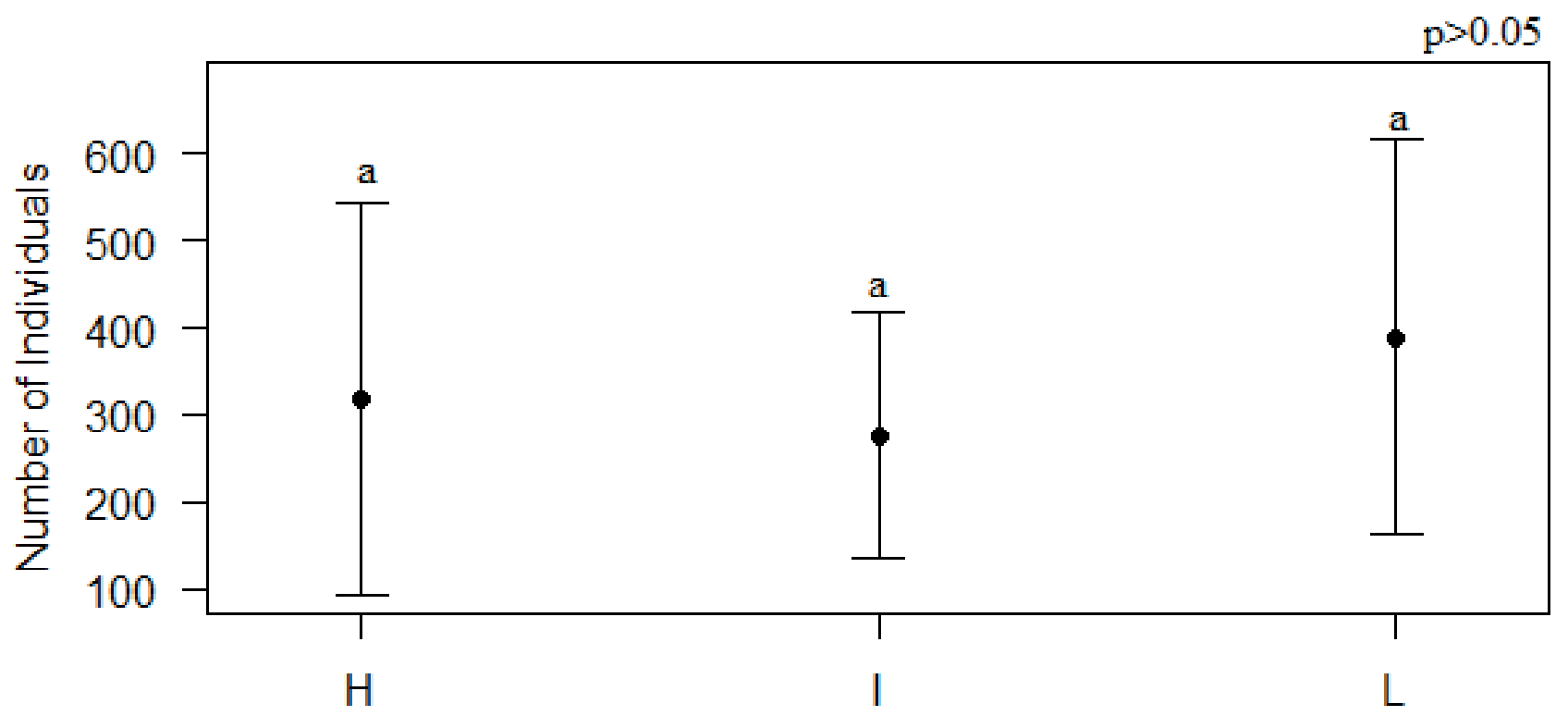

\section{Regions}

Figure 2. Total abundance of species by study region, in Ijuí River Basin, August to October 2015. Means with equal letters do not differ. H= High; $\mathrm{I}=$ Intermediate; $\mathrm{L}=$ Low. 

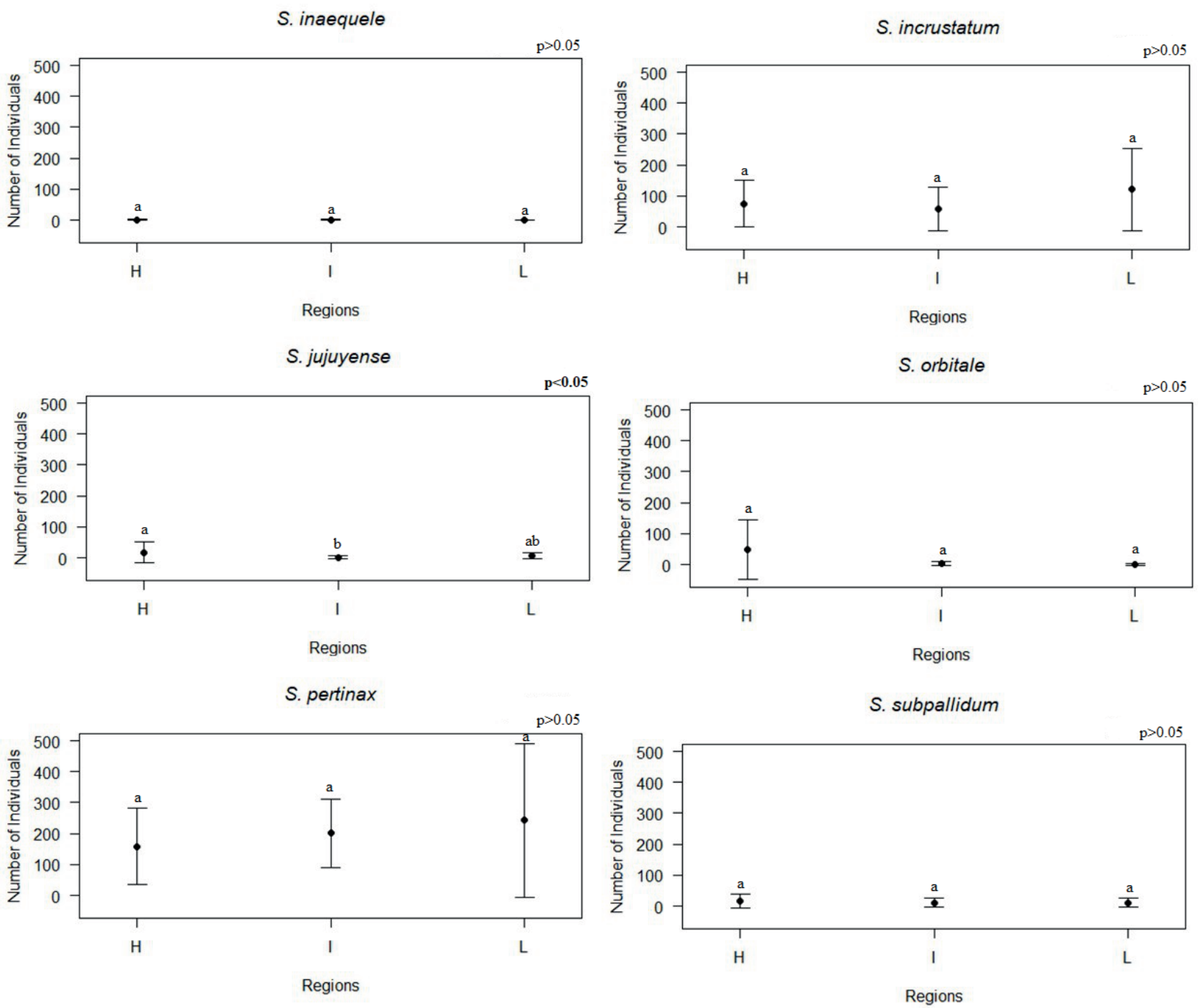

Figure 3. Abundances of the most frequent species by study region, in Ijuí River Basin, August to October 2015. In bold type, values with statistical significance. Means with equal letters do not differ. $\mathrm{H}=$ High; I= Intermediate; L= Low.

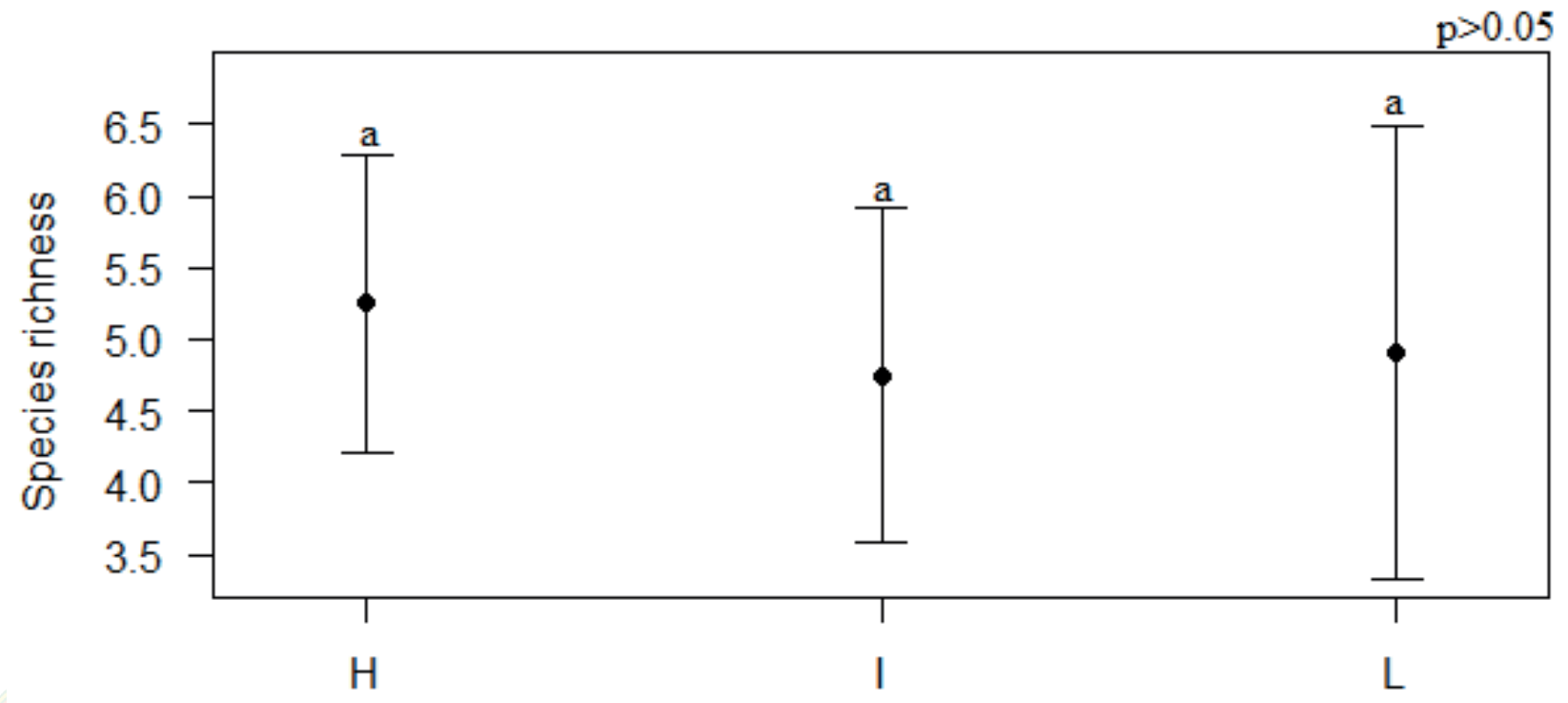

Regions

Figure 4. Species richness by study region, in Ijuí River Basin, August to October 2015. Means with equal letters do not differ. H= High; I= Intermediate; $\mathrm{L}=$ Low. 


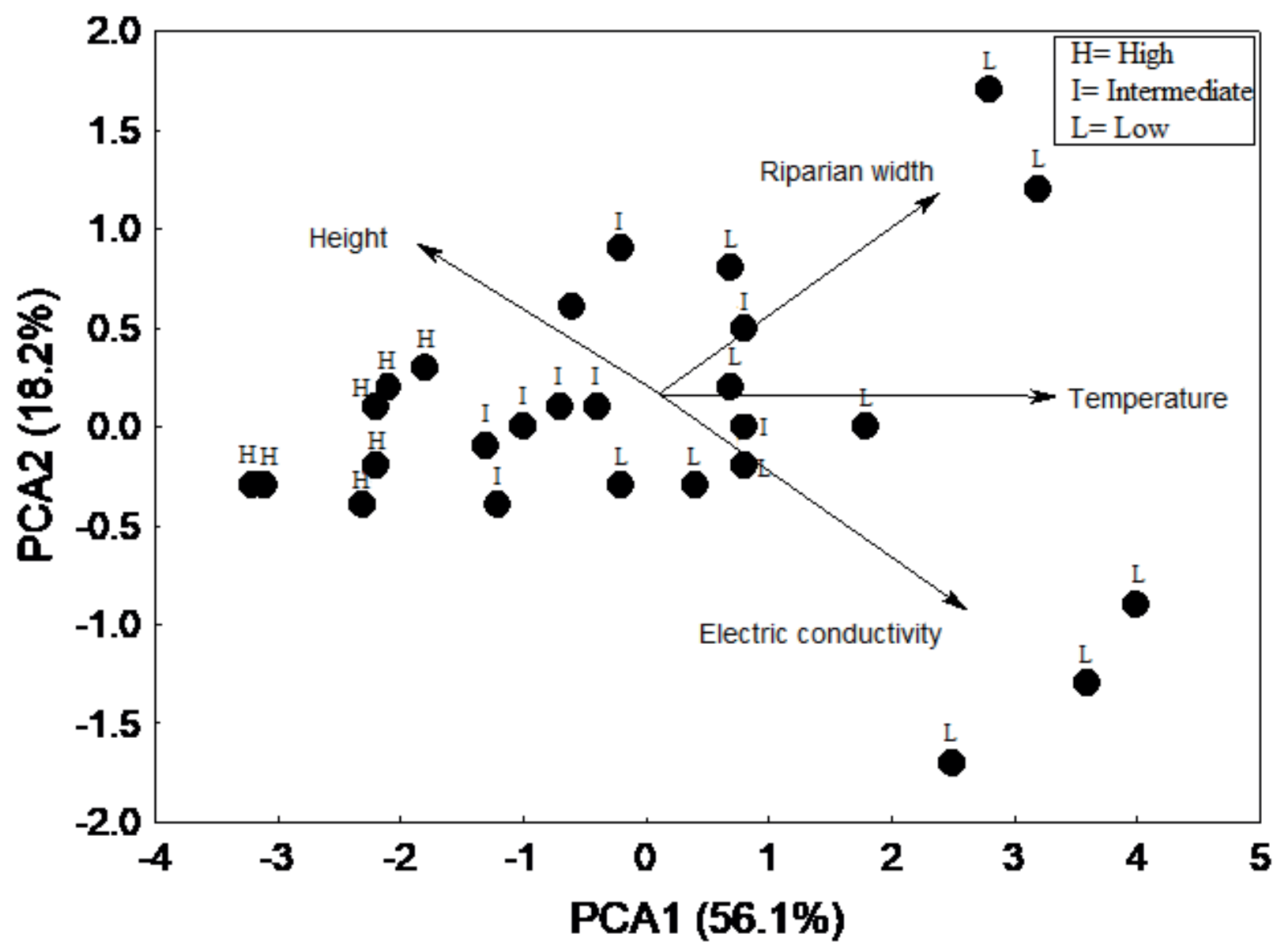

Figure 5. PCA applied to the set of abiotic factors sampled in the Ijuí River Basin, August to October 2015.

Table 2. Results for Principal Component Analysis (PCA), in Ijuí River Basin, August to October 2015. For each axis are shown the eigenvalue, the explained and accumulated variance and the eigenvector of the abiotic factors. In bold type, loadings with statistical significance are presented.

\begin{tabular}{lccc}
\hline & PCA 1 & PCA 2 & \\
\hline Eingenvalue & 2.28 & 1.83 & 18.2 \\
\% Variance & 56.1 & 0.04 & -0.22 \\
Temperature & $\mathbf{0 . 9 4}$ & 0.31 & $\mathbf{0 . 6 4}$ \\
Electric Conductivity & $\mathbf{0 . 8 9}$ & $\mathbf{0 . 4 6}$ & \\
Height & $\mathbf{0 . 4 4}$ & & \\
Riparian Width & &
\end{tabular}

\section{DISCUSSION}

Considering the information of STRIEDER (2004) and AdLER (2019), it was possible to verify that the ten species of Simuliidae found in the Ijuí River Basin in this study represent $33.3 \%$ of the total black fly species for the Rio Grande do Sul State, and 43.5\% for the northwest Mesoregion of the state. Probably, such results are related to the fact that both habitat and watershed characteristics may influence the abundance of these aquatic insects (WAINFAS 2015).

The higher abundance reported $S$. pertinax, $S$. incrustatum and $S$. orbitale in this study follows the same trend observed in other studies conducted in Rio Grande do Sul (STRIEDER \& COURSEUIL 1992; CouCEIRO et al. 2014). The high population density of $S$. pertinax, may be explained by the high tolerance of this species to organic pollutants contamination in the aquatic environments. In past studies conducted by STRIEDER et al. (2006), which were also carried out in southern Brazil, individuals of this species prospered in streams impacted with high nitrite and nitrate concentrations, showing a high capacity to inhabit environments impacted by animal husbandry. According to CosCARón (1991) and STRIEDER \& CoRSEuIL (1992), this species is one of the most uncomfortable to the human population in the south of Brazil, since it presents an anthropophilic habit.

Human interventions in lotic environments have been influencing populations of black flies, which can, on the one hand, decrease in richness, and on the other hand, increase in abundance of some species (COPPO \& LOPES 2010). These results are in accordance with Ross \& MERRITT (1978), which reported that certain conditions may advantage some species in relation to others.

Concerning the species $S$. incrustatum, which was also frequent in the study area, some authors report a preference of the species for aquatic environments of intermediate levels of pollution (VIVIANi et al. 2012; Docile et al. 2015). However, CosCARón (1991) indicates that the immature forms are associated to clean waters, as well as smaller water flows. In Rio de Janeiro, the occurrence of $S$. incrustatum was correlated to smaller streams, and consequently, of lower incidence of sun light (FIGUEIRó et al. 2006). Perhaps, this species is adapted to survive in different environments. 
Comparing to studies conducted in other Brazilian regions, the average number of 4.96 species per stream in the Ijuí River Basin was quite high (HAMAda et al. 2002; PePINELli et al. 2005). Perhaps such results are related to the fact that this study was conducted in a drainage basin, which is an ecological unit of welldefined boundaries. CoucEIRo et al. (2014), which also obtained a relatively higher species' average per water stream in the Rio Grande do Sul state, suggest that these results may be related to a non-deterministic species distribution, i.e. without the influence of several factors.

Many species were found in the three studied regions, which may have been influenced by the homogeneity of different habitats along of the basin. Possibly, the sampling sites do not present suitable characteristics to be classified as ecoregions, known as heterogeneous areas, thus limiting the distribution of black fly species. The Ijuí Drainage Basin has been heavily disturbed over time by agricultural practices, which have changed both landscape and streams (FERREIRA 2011; TRINDADE et al. 2018). Modified areas tend to be more homogeneous at an ecological perspective, which may explain the local distribution of simulids (ADLER \& MCCREAdIE 1997; MCCREAdIE \& AdLER 1998; MCCREAdIE et al. 2005; COUCEIRO et al. 2014).

The homogeneous distribution of the abundance and diversity (except $S$. jujuyense) of black flies in the three studied regions is in agreement with other studies results (FIGUEIRó et al. 2006; CoucEiro et al. 2014; ViJayan \& AndBalagan 2018). Possibly, these results are explained by the connectivity between the sample sites. Still, COUCEIRO et al. (2014) highlight that the distribution of simulids in the Rio Grande do Sul state follows a non-determinist pattern, possibly due to landscapes homogenization caused by agriculture activities. According to MATson et al. (1997), in lotic ecosystems, disruption of agricultural activities is one of the most relevant issues for the biodiversity.

S.jujuyense, which appears to be an indicator species of the upper basin, is described by CosCARón (1991) as a species associated with clear water environments, as well as with smaller streams. According to ADLER \& MCCREADIE (1997), stream size is one of the most important predictors of black fly species distribution. As expected, in the high region of Ijuí River Basin the streams are smaller, and possibly presents better environmental quality.

In the studied region, there are disturbance problems, considering the high indexes of anthropophilic hematophagous species in the adult phase (COSCARón 1991). Thus, such information may be useful to the control program of simulids in Rio Grande do Sul, indicating that an efficient control must be applied in all streams of the watershed. Furthermore, we highlight the need to preserve the environmental integrity of the aquatic ecosystems.

According to MeLo et al. (2015b), in the Ijuí River Basin the land use is essentially agricultural, which may affect the biological diversity and species distribution patterns. In this sense, our results, which reported the occurrence of ten species and no association with the analyzed abiotic factors, may be explained by the homogeneous ecological characteristics at the northwest Mesoregion of Rio Grande do Sul state, which have been under anthropogenic pressure due to farming activities. Our results highlight the need for further research, encompassing areas of different land uses and conserved areas, in order to determine if such activities are indeed related to local distribution of black flies.

\section{ACKNOWLEDGMENTS}

We thank the Universidade Federal da Fronteira Sul - campus Cerro Largo for technical support, through the availability of the Zoology Laboratory. We also thank the Fundação de Amparo à Pesquisa do Estado do Rio Grande do Sul (FAPERGS) for financial support.

\section{REFERENCES}

Adler, PH \&JW McCreadie, 1997. The hidden ecology of black flies: Sibling species and ecological scale. American Entomologist, 43: 153-62. DOI: https://doi.org/10.1093/ae/43.3.1053.

Adler, PH, DC Currie \& DM Wood, 2004. The black flies (Simuliidae) of North America. New York, Cornell University Press, $941 \mathrm{p}$.

Adler, PH, 2019. World blackflies (Diptera: Simuliidae): a comprehensive revision of the taxonomic and geographical inventory [2019]. Inventory Revision, South Carolina. Available on: <https://biomia.sites.clemson.edu/pdfs/ blackflyinventory.pdf $>$. [Accessed in: 10.iii.2019].

Begon, M, CR Townsend \& JH Harper, 2006. Ecology: from individuals to ecosystems, 4th Ed. Malden, Blackwell Pub, $738 \mathrm{p}$.

Buffolo, IRA, TMM Souza, SS Santos, T Rodrigues, LC Berbert, TN Docile \& R Figueiró, 2016. Desvendando os padrões de preferência de habitat de larvas de Simuliidae (Diptera) Neotropicais e suas implicações para o controle do vetor. Acta Biomedica Brasiliensia, 7: 109-118. DOI: https://doi.org/.18571/acbm.103.

Campos-de-Oliveira, IC, BJ Ferreira, SS Santos, K Lima-deSousa, IRA Buffolo, LB Lucena, TR Costa \& R Figueiró, 2015. Black Fly (Diptera: Simuliidae) pupae microhabitat characterization in the Itatiaia National Park, Brazil. Acta Scientiae \& Technica, 3: 43-46. DOI: https://doi. org/10.17648/uezo-ast-v3i1.93.

Coppo, TL \& J Lopes, 2010. Diversidade de Simuliidae (Diptera: Nematocera) de três cursos d' água no parque ecológico da Klabin S.A. - Telêmaco Borba, Estado do Paraná. Semina: Ciências Biológicas e Saúde, 31: 03-14. DOI: https://doi.org/10.5433/1679-0367.2010v31n1po3.

Coscarón, S, 1991. Insecta, Diptera, Simuliidae: Fauna agua dulce de la República Argentina. 2nd Ed. Buenos Aires, Fecic, 295 p.

Couceiro, SR, N Hamada, LB Sagot \& M Pepinelli, 2014. Blackfly assemblage distribution patterns in streams in disturbed areas in southern Brazil. Acta Tropica, 140: 26-33. DOI: https://doi.org/10.1016/j.actatropica.2014.07.018.

Docile, TN, R Figueiró, LH Gil-Azevedo \& JL Nessimian, 2015. Water pollution and distribution of the black fly (Diptera: Simuliidae) in the Atlantic Forest, Brazil. Revista de Biologia Tropical, 63: 683-693. DOI: https://doi.org/10.15517/RBT. V63I3.16195.

Dufrene, M \& P Legendre, 1997. Species assemblages and indicator species: the need for a flexible asymmetrical approach. Ecological Monographs, 67: 345-366. DOI: https://doi.org/10.1890/0012-9615(1997)067[0345:SAAIST ]2.0.CO;2.

Feld, CK, E Kiel \& M Lautenschlager, 2002. The indication of morphological degradation of streams and rivers using Simuliidae. Limnologica, 32: 273-288. DOI: https://doi.org/10.1016/So075-9511(02)80033-0.

Ferreira, FW, 2011. A bacia do Rio Ijuí e seus peixes: diversidade e preservação, pp. 77-95. In: Astrid, H, JR, Martins (Org). Artigos correlacionados com a bacia hidrográfica do Rio Ijuí. Santo Ângelo: EDIURI, 157 p.

Figueiró,R,CJPCAraújo-Coutinho,LHGAzevedo,ESNascimento \& RF Monteiro, 2006. Spatial and Temporal Distribution of Blackflies (Diptera: Simuliidae) in the Itatiaia National Park, Brazil. Neotropical Entomology, 35: 542-550. DOI: https://doi.org/10.1590/S1519-566X2006000400018.

Figueiró, R, ES Nascimento, LH Gil-Azevedo, M Maia-Herzog \& RF Monteiro, 2008. Local distribution of blackfly (Diptera, Simuliidae) larvae in two adjacent streams: the role of water current velocity in the diversity of blackfly larvae. Revista Brasileira de Entomologia, 52: 452-454. DOI: https://doi.org/10.1590/So085-56262008000300020.

Figueiró, R \& LH Gil-Azevedo, 2010. The role of the Neotropical blackflies (Diptera: Simuliidae) as vectors 
of the onchocerciasis: a short overview of the ecology behind the disease. Oecologia Australis, 14: 745-755. DOI: https://.doi.org/10.4257/oeco.2010.1403.10.

Hamada, N, JW McCreadie \& PH Adler, 2002. Species richness and spatial distribution of blackflies (Diptera: Simuliidae) in streams of Central Amazonia, Brazil. Freshwater Biology, 47: 31-40. DOI: https://doi.org/10.1046/j.13652427.2002.00778.x.

Illésová, D, J Halgos \& I Krno, 2008. Blackfly assemblages (Diptera, Simuliidae) of the Carpathian river: habitat characteristics, longitudinal zonation and eutrophication. Hydrobiologia, 598: 163-174. DOI: https://doi.org/10.1007/ s10750-007-9148-4.

Illésová, D, P Beracko, I Krno \& J Halgos, 2010. Effects of land use on black fly assemblages (Diptera: Simuliidae) in submontane rivers (West Carpathians, Slovakia). Biologia, 65: 892-898. DOI: https://doi.org/10.2478/s11756-010-0096-5.

Jackson, DA, 1993. Stopping rules in principal components analysis: a comparison of heuristical and statistical approaches. Ecology: Ecological Society of America, 74: 2204-2214. DOI: https://doi.org/10.2307/1939574.

Kuvangkadilok, C, C Boonkemtong \& S Phayuhasena, 1999. Distribution of the larvae of blackflies (Diptera: Simuliidae) at Doi Inthanon National Park, northern Thailand. The Southeast Asian Journal of Tropical Medicine and Public Health, 30: 228-237.

Landeiro, VL, M Pepinelli \& N Hamada, 2009. Species richness and distribution of black flies (Diptera: Simuliidae) in the Chapada Diamantina region, Bahia, Brazil. Neotropical Entomology, 38: 332-339. DOI: http://doi.org/10.1590/ S1519-566X2009000300006.

Legendre, P \& L Legendre, 1998. Numerical ecology, $2^{\text {nd }}$ Ed. Amsterdan, Elsevier, $852 \mathrm{p}$.

Leinz, V, 1949. Contribuição à geologia dos derrames basálticos do sul do Brasil., São Paulo: Universidade de São Paulo (Boletim CIII), $61 \mathrm{p}$.

Malmqvist, B, Y Zhang \& PH Adler, 1999. Diversity, distribution and larval habitats of North Swedish blackflies (Diptera: Simuliidae). Freshwater Biology, 42: 301-314. DOI: https://doi.org/10.1046/j.1365-2427.1999.444497.x.

Matson, PA, WJ, Parton, AG Power \& MJ Swift, 1997. Agricultural intensification and ecosystem properties. Science, 277: 504509. DOI: https://doi.org/10.1126/science.277.5325.504.

McCreadie, J, PH Adler \& MH Colbo, 1995. Community structure of larval black flies (Diptera: Simuliidae) from the Avalon Peninsula, Newfoundland. Annals of the Entomological Society of America, 88: 51-57. DOI: https://doi.org/10.1093/ aesa/88.1.51.

McCreadie, JW \& PH Adler, 1998. Scale, time, space, and predictability: species distributions of preimaginal black flies (Diptera: Simuliidae). Oecologia, 114: 79-92. DOI: https://doi.org/10.1007/s004420050423.

McCreadie, JW, PH Adler \& N Hamada, 2005. Patterns of species richness for blackflies (Diptera: Simuliidae) in the Neartic and Neotropical regions. Ecological Entomology, 30: 201-209. DOI: https://doi.org/10.1111/j.0307-6946.2005.00681.x.

McCreadie, JW, PH Adler, ME Grillet \& N Hamada, 2006. Sampling statistics in understanding distributions of black fly larvae (Diptera: Simuliidae). Acta Entomologica Serbica, Supplement: 89-96.

Melo, TM, I Wottrich, JA Louzada \& F Helfer, 2015a. Avaliação do atendimento da demanda hídrica da cultura do milho através da subirrigação. Revista Brasileira de Agricultura Irrigada, 4: 226-233. DOI: https://doi.org/10.7127/rbai.v4n400034.

Melo, TM, JAS Louzada \& OC Pedrollo, 2015b. Trends in extreme indices and seasonal analysis of precipitation and temperature in the northwest region of Rio Grande do Sul, Brazil. American Journal of Climate Change 4: 187-202. DOI: https://doi.org/10.4236/ajcc.2015.43015.

Pepinelli, M, S Trivinho-Strixino \& N Hamada, 2005. Imaturos de Simuliidae (Diptera, Nematocera) e caracterização de seus criadouros no Parque Estadual Intervales. Revista Brasileira de Entomologia, 49: 527-530. DOI: https://doi.org/10.1590/ So085-56262005000400012.

Pepinelli, M, 2008. Simuliidae (Diptera, Nematocera) do Estado de São Paulo. Tese (Doutorado em Ecologia e Recursos) Universidade Federal de São Carlos.

Rabha, R, S Dhiman, K Yadav, S Hazarika, RK Bhola \& V Veer, 2013. Influence of water physicochemical characteristics on Simuliidae (Diptera) prevalence in some streams of Meghalaya, India. Journal of Vector Borne Diseases, 50: 1823.

Ross, DH \& RW Merritt, 1978. The larval instars and population dynamics of Five species of black flies (Diptera: Simuliidae) and their responses to select environmental factores. Canadian Journal of Zoology, 56: 1633-1642. DOI: https://doi.org/10.1139/z78-226.

Shelley, AJ, LM, Hernández, M Maia-Herzog, APA Luna-Dias \& PR Garritano, 2010. The blackflies (Diptera: Simuliidae) of Brazil. In: Arias, JR, S Golovach, KM Wantzen \& E Domínguez (Eds.). Aquatic Biodiversity in Latin America. Sofia, Pensoft Pub., 821 p.

Srisuka, W, H Takaoka, Y Otsuka, M Fukuda, S Thongsahuan \& K Taai, 2015. Seasonal biodiversity of black flies (Diptera: Simuliidae) and elevation of ecological factors influencing species distribution at Doi Pha Hom Poh National Park, Thailand. Acta Tropica, 149: 212-219. DOI: https://doi.org/10.1016/j.actatropica.2015.05.024.

Strieder, MN \& E Corseuil, 1992. Atividades de hematofagia em Simuliidae (Diptera,Nematocera) na Picada Verão, Sapiranga, RS - Brasil. Acta Biologica Leopoldensia, 14: 75-98.

Strieder, MN \& V Py-Daniel, 1999. Espécies de Inaequalium (Diptera, Simuliidae): dados bionômicos e chaves para sua identificação. Biociências, 7: 43-72.

Strieder, MN, JE Santos \& AMO Pês, 2002. Diversidade e distribuição de Simuliidae (Diptera, Nematocera) nogradiente longitudinal da bacia do rio dos Sinos, no Rio Grande do Sul, Brasil. Entomologia y Vectores, 9: 527-540.

Strieder, MN, 2004. Espécies de simulídeos (Diptera, Nematocera, Simuliidae) no Rio Grande do Sul, Brasil: distribuição geográfica. Entomologia y Vectores, 11: 117-121.

Strieder, MN, 2005. Controle eficiente dos borrachudos. Ciência Hoje, 36: 70-71.

Strieder, MN, JE Santos \& EM Vieira, 2006. Distribuição, abundância e diversidade de Simuliidae (Diptera) em uma bacia hidrográfica impactada no sul do Brasil. Revista Brasileira de Entomologia, 50: 119-124. DOI: https://doi.org/10.1590/Soo85-56262006000100018.

Trindade, JP, DS Rocha \& LBS Volk, 2018. Uso da terra no Rio Grande do Sul: ano de 2017. Bagé, Embrapa Pecuária Sul, 18 p.

Tucci, CEM, 2003. Variabilidade climática e o uso do solo na bacia brasileira do Prata, pp.163-242. In: Tucci, CEM \& BPF Braga (Eds). Clima e Recursos Hídricos no Brasil. Porto Alegre: Associação Brasileira de Recursos Hídricos, 348 p.

Vijayan, S \& S Anbalagan, 2018. Assemblage pattern and seasonality of larval black flies (Simuliidae: Diptera) in a stream of Southern Eastern Ghats. International Journal of Current Trends in Science and Technology 8: 20187-20196. Available in: <http://currentsciences.info/10.15520/ctst. v8io3.383.pdf $>$.

Viviani, ABP, CJPC Araújo-Coutinho, RB Moraes, HB Gil, R Leung \& AFM Camargo, 2012. Distribuição e abundância de larvas de Simulium spp. em córregos do estado de São Paulo nos diferentes níveis de qualidade da água. Neotropical Biology and Conservation, 7: 48-56. DOI: https://doi.org/10.4013/ nbc.2012.71.07.

Wainfas, RL, 2015. Distribuição espacial e temporal de Simuliidae (Diptera) em córregos sob a influência de fatores abióticos e antrópicos da área da UHE peixe angical, Tocantins, Brasil. Dissertação (Mestrado em Biodiversidade e Saúde) - Instituto Oswaldo Cruz. 
Wollmann, CA \& E Galvani, 2012. Caracterização climática regional do Rio Grande do Sul: Dos estudos estáticos ao entendimento da gênese. Revista Brasileira de Climatologia, 11: 87-103. DOI: https://doi.org/10.5380/abclima. v11io. 28586.
Ya'cob, Z, H Takaoka, P Pramual, VL Low \& M SofianAzirun, 2016. Distribution pattern of black fly (Diptera: Simuliidae) assemblages along an altitudinal gradient in Peninsular Malaysia. Parasites \& Vectores, 9: 1-16. DOI: https://doi.org/10.1186/s13071-016-1492-7.

\section{Suggestion citation:}

Menzel, TC, SM Hentges, DAR Tataje, MN Strieder, 2019. Diversity and spatial distribution of black flies (Diptera: Simuliidae) in the Ijuí river drainage basin, Rio Grande do Sul, Brazil. EntomoBrasilis, 12 (2): 47-56.

Available on: doi:10.12741/ebrasilis.v12i2.845

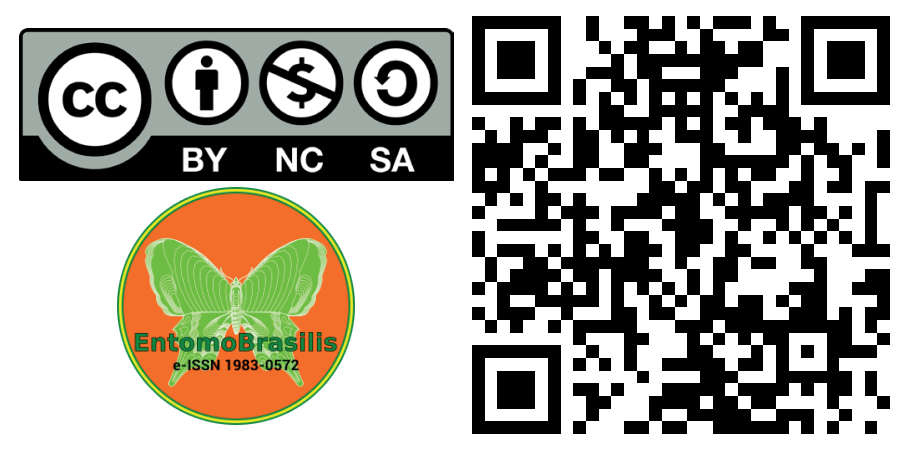

This article has two attachment

Attachment 1. Geographic coordinates and associated abiotic factors (mean) in the 27 sampling points of the Ijuí River Basin, August to October 2015 .

\begin{tabular}{|c|c|c|c|c|c|c|c|c|}
\hline $\begin{array}{l}\text { Stream/ } \\
\text { Altitude }\end{array}$ & GPS & Altitude (m) & $\begin{array}{c}\text { Water } \\
\text { Temperature } \\
\left({ }^{\circ} \mathrm{C}\right)\end{array}$ & $\mathrm{pH}$ & $\begin{array}{c}\text { Electrical } \\
\text { Conductivity } \\
(\mathrm{S} / \mathrm{cm})\end{array}$ & $\begin{array}{l}\text { Width of the } \\
\text { Streams (m) }\end{array}$ & $\begin{array}{l}\text { Oxigen } \\
\text { Dissolved } \\
(\mathrm{mg} / \mathrm{L})\end{array}$ & $\begin{array}{l}\text { Atmospheric } \\
\text { Pressure } \\
\text { (mm Hg) }\end{array}$ \\
\hline \multicolumn{9}{|c|}{ Low } \\
\hline P26 & $\begin{array}{c}28^{\circ} 04^{\prime} 15.02 " \mathrm{~S} \\
55^{\circ} 11^{\prime} 10.81^{\prime \prime} \mathrm{O}\end{array}$ & 131 & 23.4 & $7 \cdot 51$ & 151.6 & 10 & $3 \cdot 31$ & 751.1 \\
\hline P27 & $\begin{array}{l}28^{\circ} 02{ }^{\prime} 02.58^{\prime \prime} \mathrm{S} \\
55^{\circ} \mathrm{O} 6^{\prime} 33.16^{\prime \prime} \mathrm{O}\end{array}$ & 114 & 23.4 & $7 \cdot 56$ & 205.7 & 4.5 & 3.26 & 750.3 \\
\hline P25 & $\begin{array}{l}28^{\circ} 12^{\prime} 58.76^{\prime \prime} \mathrm{S} \\
55^{\circ} \mathrm{O} 2^{\prime} 14.15^{\prime \prime} \mathrm{O}\end{array}$ & 131 & 23.1 & $7 \cdot 55$ & 160.1 & $7 \cdot 5$ & 3.61 & $747 \cdot 3$ \\
\hline P24 & $\begin{array}{l}28^{\circ} 16 \text { '19.93” S } \\
54^{\circ} 55^{\prime} 01.44^{\prime \prime} \mathrm{O}\end{array}$ & 200 & 22.6 & $7 \cdot 35$ & 81.6 & $7 \cdot 5$ & 3.13 & 743.8 \\
\hline P22 & $\begin{array}{c}28^{\circ} 14^{\prime} 11.81^{\prime \prime} \mathrm{S} \\
54^{\circ} 47^{\prime} 04.59^{\prime \prime} \mathrm{O}\end{array}$ & 190 & 22 & $7 \cdot 37$ & 83.4 & 2.5 & 4.74 & 742.1 \\
\hline P23 & $\begin{array}{l}28^{\circ} 15^{\prime} 38.24^{\prime \prime} \mathrm{S} \\
54^{\circ} 49^{\prime} 21.94^{\prime \prime} \mathrm{O}\end{array}$ & 192 & 22.1 & $7 \cdot 37$ & 44.1 & 6.5 & $3 \cdot 31$ & 742.1 \\
\hline $\mathrm{P}_{21}$ & $\begin{array}{l}28^{\circ} 14^{\prime} 34.84^{\prime \prime} \mathrm{S} \\
54^{\circ} 39^{\prime} 03.07^{\prime \prime} \mathrm{O}\end{array}$ & 182 & 22.1 & 7.83 & 93.7 & 15 & 5.24 & 743.9 \\
\hline $\mathrm{P} 15$ & $\begin{array}{l}28^{\circ} 12^{\prime} \mathrm{O} 2.13 \text { " S } \\
54^{\circ} 38^{\prime} 19.13^{\prime \prime} \mathrm{O}\end{array}$ & 163 & 22.1 & 7.46 & 119.6 & 6.5 & 2.12 & 741.7 \\
\hline $\mathrm{P} 12$ & $\begin{array}{l}28^{\circ} 09^{\circ} 02.49^{\prime \prime} \mathrm{S} \\
54^{\circ} 37^{\prime} 30.38^{\prime \prime} \mathrm{O}\end{array}$ & 210 & 20.7 & 6.89 & 84.2 & 2 & 3.5 & 738.6 \\
\hline $\mathrm{P} 14$ & $\begin{array}{l}28^{\circ} 11^{\prime} 33 \cdot 32 " \mathrm{~S} \\
54^{\circ} 38^{\prime} 18.85 " \mathrm{O}\end{array}$ & 167 & 22.1 & 7.43 & 119.6 & 6.5 & 2.43 & 741.8 \\
\hline $\mathrm{P} 13$ & $\begin{array}{c}28^{\circ} 10^{\prime} 11.05 " \mathrm{~S} \\
54^{\circ} 37^{\prime} 29.20^{\prime} \mathrm{O}\end{array}$ & 192 & 21.7 & $7 \cdot 33$ & 109.5 & 3.5 & 2.09 & 739.9 \\
\hline \multicolumn{9}{|c|}{ Intermediate } \\
\hline P11 & $\begin{array}{l}28^{\circ} 16^{\prime} 20.35 \text { ” S } \\
54^{\circ} 17^{\prime} 00.08^{\prime \prime} \mathrm{O}\end{array}$ & 245 & 21 & $7 \cdot 41$ & 68.7 & 10 & 2.7 & 740.3 \\
\hline
\end{tabular}


Attachment 1. Continued...

\begin{tabular}{|c|c|c|c|c|c|c|c|c|}
\hline $\begin{array}{l}\text { Stream/ } \\
\text { Altitude }\end{array}$ & GPS & Altitude (m) & $\begin{array}{c}\text { Water } \\
\text { Temperature } \\
\left({ }^{\circ} \mathrm{C}\right)\end{array}$ & $\mathrm{pH}$ & $\begin{array}{c}\text { Electrical } \\
\text { Conductivity } \\
\text { (S/cm) }\end{array}$ & $\begin{array}{l}\text { Width of the } \\
\text { Streams }(\mathrm{m})\end{array}$ & $\begin{array}{l}\text { Oxigen } \\
\text { Dissolved } \\
(\mathrm{mg} / \mathrm{L})\end{array}$ & $\begin{array}{c}\text { Atmospheric } \\
\text { Pressure } \\
\text { (mm Hg) }\end{array}$ \\
\hline $\mathrm{P9}$ & $\begin{array}{l}28^{\circ} 16 \text { '50.82" S } \\
54^{\circ} 15^{\prime} 01.39 " \mathrm{O}\end{array}$ & 262 & 20.1 & $7 \cdot 35$ & 58.3 & 8 & 2.7 & 736.8 \\
\hline P10 & $\begin{array}{c}28^{\circ} 15^{\prime} 16.79 " \mathrm{~S} \\
54^{\circ} 14^{\prime} 00.82 " \mathrm{O}\end{array}$ & 273 & 20.1 & 7.25 & 59.6 & 5 & 2.81 & 735.6 \\
\hline P8 & $\begin{array}{l}28^{\circ} 19 \text { '05.05" S } \\
54^{\circ} 14^{\prime} 04.42^{\prime \prime} \mathrm{O}\end{array}$ & 202 & 21.1 & 7.62 & $67 \cdot 3$ & 10 & 3.41 & 742.1 \\
\hline $\mathrm{P}_{7}$ & $\begin{array}{l}28^{\circ} 15,53.86 " \mathrm{~S} \\
54^{0} 12^{\prime} 26.09 " \mathrm{O}\end{array}$ & 265 & 19.5 & $7 \cdot 56$ & 57.4 & 7 & $4 \cdot 38$ & 736.4 \\
\hline P2O & $\begin{array}{l}28^{\circ} 22^{\prime} 23.58^{\prime \prime ~ S ~} \\
54^{\circ} 11^{\prime} 16.08^{\prime \prime} \mathrm{O}\end{array}$ & 217 & 18.4 & 7.29 & 61.6 & 10 & 1.03 & 747.9 \\
\hline P6 & $\begin{array}{l}28^{\circ} 14^{\prime} 43.63^{\prime \prime} \mathrm{S} \\
54^{\circ} \mathrm{O} 7^{\prime} 00.40^{\prime \prime} \mathrm{O}\end{array}$ & 252 & 19.6 & 7.94 & 156.7 & 10 & 6.3 & 737.6 \\
\hline P19 & $\begin{array}{l}28^{\circ} 21^{\prime} 28.92 " \mathrm{~S} \\
54^{\circ} \mathrm{O} 4^{\prime} 00.20 " \mathrm{O}\end{array}$ & 227 & 18.9 & 6.35 & 89.5 & 2.5 & 1.04 & 747.9 \\
\hline \multicolumn{9}{|c|}{ High } \\
\hline $\mathrm{P}_{5}$ & $\begin{array}{c}28^{\circ} 17^{\prime} 21.51^{\prime \prime} \mathrm{S} \\
53^{\circ} 54^{\prime} 13.92 " \mathrm{O}\end{array}$ & 266 & 19.9 & 7.12 & 26.4 & 10 & 4.81 & 742.7 \\
\hline P1 & $\begin{array}{l}28^{\circ} 14^{\prime} 27.71^{\prime \prime} \mathrm{S} \\
53^{\circ} 45^{\prime} 11.67^{\prime \prime} \mathrm{O}\end{array}$ & 313 & 15.6 & 7.15 & 58.1 & 9 & 5.65 & 740.5 \\
\hline P2 & $\begin{array}{l}28^{\circ} 12^{\prime} \mathrm{O} 4.74 \text { ” S } \\
53^{\circ} 43^{\prime} 40.41^{\prime \prime} \mathrm{O}\end{array}$ & 367 & 15.4 & 6.91 & 62.2 & 2.5 & 4.42 & 736 \\
\hline $\mathrm{P}_{3}$ & $\begin{array}{c}28^{\circ} 11^{\prime} 19.35^{\prime \prime} \mathrm{S} \\
53^{\circ} 43^{\prime} 31.00 " \mathrm{O}\end{array}$ & 379 & 16 & 7.09 & 43.7 & 8 & 3.23 & 733.5 \\
\hline $\mathrm{P}_{4}$ & $\begin{array}{l}28^{\circ} 10^{\prime} 01.09 " \mathrm{~S} \\
53^{\circ} 42^{\prime} 02.31^{\prime \prime} \mathrm{O}\end{array}$ & 388 & 16.2 & 7.04 & $45 \cdot 7$ & 10 & 3.6 & 735 \\
\hline P17 & $\begin{array}{l}28^{\circ} 20^{\prime} 12.02 " \mathrm{~S} \\
53^{\circ} 24^{\prime} 19.61^{\prime \prime} \mathrm{O}\end{array}$ & 452 & 17.5 & 6.29 & 30 & $5 \cdot 5$ & 1.52 & 729 \\
\hline P16 & $\begin{array}{l}28^{\circ} 20^{\prime} 12.12 ” \mathrm{~S} \\
53^{\circ} 25^{\prime} 24.27^{\prime \prime} \mathrm{O}\end{array}$ & 452 & 18.4 & 5.67 & $47 \cdot 7$ & 3 & 0.49 & 728.8 \\
\hline $\mathrm{P} 18$ & $\begin{array}{c}28^{\circ} 17^{\prime} 31.73 \text { " S } \\
53^{\circ} 27^{\prime} 29.94 " \mathrm{O}\end{array}$ & 419 & $17 \cdot 3$ & 6.56 & 51.3 & $4 \cdot 5$ & $7 \cdot 37$ & 731 \\
\hline
\end{tabular}

Attachment 2. Analysis of variance, with mean and standard deviation for the physicochemical and environmental parameters among the high, intermediate and low regions of the Ijuí River Basin, August to October 2015. Means with equal letters in the same line do not differ by Tukey's test at the $5 \%$ level of significance.

\begin{tabular}{lcccc}
\hline \multicolumn{1}{c}{ Abiotic factors } & P & \multicolumn{2}{c}{ Regions } \\
\cline { 3 - 5 } & & High & Intermediate & Low \\
\hline Temperature & $1.71 \mathrm{E}-07$ & $17.04 \pm 1.55 \mathrm{a}$ & $19.84 \pm 0.94 \mathrm{~b}$ & $22.3 \pm 0.79 \mathrm{c}$ \\
Atmospheric Pressure & 0.00102 & $734.56 \pm 5.09 \mathrm{a}$ & $740.58 \pm 5.00 \mathrm{~b}$ & $743.87 \pm 4.05 \mathrm{~b}$ \\
Dissolved oxygen (mg/L) & 0.587 & $3.89 \pm 2.20 \mathrm{a}$ & $3.05 \pm 1.73 \mathrm{a}$ & $3.34 \pm 0.98 \mathrm{a}$ \\
Electric conductivity & 0.00121 & $45.64 \pm 12.45 \mathrm{a}$ & $77.39 \pm 33.79 \mathrm{ab}$ & $113.92 \pm 44.95 \mathrm{~b}$ \\
$\mathrm{pH}$ & 0.00275 & $6.72 \pm 0.53 \mathrm{a}$ & $7.35 \pm 0.46 \mathrm{~b}$ & $7.42 \pm 0.23 \mathrm{~b}$ \\
Altitude & $1.03 \mathrm{E}-09$ & $379.5 \pm 65.03 \mathrm{a}$ & $242.88 \pm 25.19 \mathrm{~b}$ & $170.18 \pm 32.01 \mathrm{c}$ \\
Stream width & 0.664 & $6.56 \pm 3.08 \mathrm{a}$ & $7.81 \pm 2.83 \mathrm{a}$ & $6.55 \pm 3.68 \mathrm{a}$ \\
\hline
\end{tabular}

